\title{
Non-State Security Actors and Rural Community Development in Niger Delta Region, Nigeria
}

\author{
Goddey Wilson \\ http://dx.doi./org/10.4314/ujah.v19i1.6
}

\begin{abstract}
Non-State security actors are organised agitating armed groups that operate in the Niger Delta region as social movements to express their anger, sometimes violently arising from the perceived frustration and marginalisation by the Nigerian State and its agents in the region. They are classified into three groups, the militia groups, the cult groups, and gangs, who operate independently in the region. This research is aimed at identifying the characteristics and activities of the non-state security actors and their impact on development trajectory of their host communities. The study is carried out in the Niger Delta communities within the period of 2000-2017. We adopted frustration-aggression theory as our theoretical framework of analysis. Primary and secondary sources of data were generated, and analysed to achieve the objectives of the study. In our findings, we noted that the non-state security actors have some basic characteristics that are peculiar to them in the region. They aim at demanding for equitable distribution of the State resources for the development of the rural communities in the region. In the process, they carry out several activities to achieve their aim. Regrettably, these activities of the non-state security actors have more negative than positive impact on the rural communities in the region. The
\end{abstract}


study proffered strategies to curb the activities of the non-state security actors to enhance rural community development.

Key words: Non-State Security Actors, rural community development, Niger Delta, frustration, aggression

\section{Introduction}

Niger Delta region is an economically viable region associated with different forms of arms struggle and violence arising from the agitations of the people for resource control and development of the rural communities in the region. The agitation is based on the perceived deprivation and exploitation of the resources of the region by the Nigerian State and its agents. It all started as a peaceful agitation, making and presenting of position papers, and holding conferences with communiqué asking the government and multinational institutions in the region to attend to the development needs of the people. In the process, the people applied several strategies to drive home their demands for resources control and development of the region.

However, in recent time, the peaceful agitations have graduated to violent attacks and deadly arms struggle in the region (Wilson, 2014). Many scholars including Ekanamah (2010) and Wilson (2012) argue that the agitations later became violent and led to the formation of different armed groups (ethnic militia and cult groups) by the aggrieved youths as a social movement and platform for the agitation. These armed groups keep on increasing in number, as new groups are formed while old ones recruit new members and train them on the operational mechanisms for their violent attacks. With several arms in their possession, they carry out regular violent activities in their host communities against both the individuals and the state, thereby creating security challenges 
in their communities. Unfortunately, while these groups aim at controlling the resources of the region for the development of the region, the violent activities of the same groups affect the development of the communities in the region. These groups create insecurity situation in the communities and discourage investors and development activities in the communities. The agitating groups constitute themselves into security actors in their communities without state authority, and the study classifies them as non-state security actors. In view of the above, it is the aim of this study to identify the characteristics and activities of the nonstate security actors and its implications on the development of their host communities in the Niger Delta region. The study covers the communities in the region between the periods of 2000-2017. Frustration-Aggression theory was used as the theoretical framework of analysis, and primary and secondary data were used to achieve the objectives of the study.

\section{Conceptual Discourse}

Community Development

Scholars within the fields of social and environmental sciences have explained community development from different perspectives, but centred on change and growth in the community with the aim of improving the well-being of the people. To Carson (2017), community development is the process of identifying and addressing the community needs. As a process, community development involves continuous procedure in identification of those things so needed by the people, and providing them for the survival of the people in the community. The people needs' implies the "basic needs", and are the basic infrastructure needed for human survival in the community, such as good road, 
electricity, hospital, school, market, drinkable water etc. The adequate or order wise of these basic needs determines the development rate in such community. Although in most Niger Delta communities, it appears these basic infrastructures are lacking.

Christenson and Robinson (1989) opined that community development is a process that increases choice of living and coming together of the people and taking decisions to initiate actions to change their cultural, social, political and environmental situation. Similarly, Wilson (2016:53) argues that community development involves group actions to initiate the process of change in their communities. This change is aimed at improving the living standard of the people and enhancing the community growth. The views of the above scholars clearly define the situation in Niger Delta communities, as the perceived absence of basic needs for survival in the communities necessitated the coming together of the people to form agitating groups for resource control and development of their communities.

In his view, Biggs (1999) sees community development as a process where people come together with the government agencies to improve the living conditions of the people in the community and integrating the people into the life of the nation to enable them contribute meaningfully to the national progress. Flora and Flora (1993) corroborate with the above view and add that community development requires collective action of the people with government. This collective action involves interaction within members of the community and collaboration with the government for development of their community. It requires self-help by the people and integrating the people with their neighbours and government to facilitate development in the communities. To achieve community development, therefore requires a safe 
environment and willingness of the people to embrace the development. However, the above views appear not likely to be the case in the Niger Delta region, as the coming together of the people to interact and initiate change for development of their communities gave room in some instances to the formation of various ethnic militia groups, cult groups and gangs in the region as a social movement to agitate for the development of the rural communities in the region. Unfortunately, while these groups and gangs aimed at attracting development to their communities, their activities scare away potential investors and in that way elude development to their communities due to their security posture.

\section{Non-State Security Actors (NSSA)}

Non-State Security Actors (NSSA) is an emerging concept in security studies, particularly in international politics. In most cases, scholars explain the concept within the scope of Non-State Actors (NSA). Oguyemi, Tella \& Venditta (2005) stated that NSA as a concept became prominent in academic studies in the year, 2000 following the outcome of the Cotonou Agreement in 2000 that established the cooperation mechanism between countries. European Commission (2012) adds that the concept of Non-State Actors was popularised by the Cotonou Agreement in 2000 and used to explain the development cooperation between the countries in European Union, Africa, Caribbean and Pacific.

The NSA is further used to identify the non-governmental actors in the state, and its activities could be either positive or detrimental to development of the state. These actors are entities, institutions, and/or groups that operate in the state without the state control on its activities. DCAF \& Geneva Call (2015) sees the Non-State Actors as organised groups with basic command structure and defined operations, and without state control on its 
affairs. They employ force and in most cases use violence to achieve their objectives in the state. These groups include, but not limited to rebels, militias, religious groups, cult groups, gangs, vigilantes, community and traditional leaders, etc .

Upon the above, this study classifies the NSA in Niger Delta region as Non-State Security Actors and sees them as organised armed security groups with defined command structure and operations, without the state control on their activities. Englehart (2016:172) sees the non-state security actors as independent armed groups that have the capacity to organise violence in the state without the state authority stopping their actions. Similarly, Rosenthal (2008) adds that the Non-state security actors are more of organised armed groups that carry out violence to enrich themselves with criminal intensions in the state. These armed security groups are group of ethnic militias, cult groups, gangs, community vigilantes, and community and youth leaders in the Niger Delta region, who operate independently, fund their activities and carry out several violent attacks in the region.

They operate in different rural communities with different names and identity, but with the focal objective of using violence to demand for their own fair share of the proceeds from their regional resources. Specifically, this study groups the Non-State Security Actors (NSSA) in Niger Delta region into three prominent groups namely, Ethnic Militias (militants), the Cult Groups, and the Gangs. For the purpose of this study, the term Non-State Security Actors would be used interchangeably with armed groups. According to Kemedi (2006) the militias are "the top of the pecking order when viewed from key indices as legitimacy with the grass-root, quality of training, weaponry, leadership and organisation, and political savvy". This is the true situation in the region, as the ethic militias in Niger Delta appears to be the most 
organised armed group of all the armed groups with heavy and small arms in their possession to carry out their operations. Its main operation is targeted at the oil installations, oil personnel, and state institutions in the region. These armed groups include the Niger Delta Vigilante (NDV), Niger Delta People Volunteer Force (NDPVF), Egbesu, Isein, Ice Landers, Green Landers, etc. They have the highest recognition and patronage in the region by both politicians and international communities, and are more organised in their violent operation against the state.

The Cult Groups are the intermediary actors who recruit their members from the rural communities, churches, schools, socio-cultural and political organisations in the region to carry out their criminal activities. They are brutal and violent in their activities and membership is always secret. They are often classified in the region as secret cults with ritual activities. Such armed groups are Deewell, Deebam, Icelander, White Chelsea, Black Banter, the Disciples, the Outlaws, the Apostles, the Duck Pam etc. The Gangs are the small groups that operate within the neighbourhoods in the rural communities of the region. They are also violent in their activities, and often influenced by the regular drugs they take. This armed group is usually manipulated by the local politicians to carry out violent activities during political and democratic process in the rural communities. Although not properly organised like the militias and cult groups, but pays allegiance to them.

\section{Theoretical Framework of Analysis}

Frustration- Aggression theory

Frustration-Aggression theory is used as our theoretical framework of analysis to explain the rationale behind the formation and activities of the Non-State Security Actors in Niger Delta region, 
and its effects on the rural communities' development in the region. The theory was first used by Dollard, Dood, Miller, Mowrer, \& Sear (1939) as psychologists in their academic publication titled "Frustration - Aggression", and late popularised by Miller, Sears, Mowrer, Dood, \& Dollard, (1941) in another research work titled "The Frustration- Aggression Hypothesis". Ever since, the theory has been prominent in their explanation of the causes of violence and its attendant effects on the organisation/society.

Crossman (2014) states that Frustration-Aggression theory explains the formation of groups by the people as a social movement to carry out aggressive and violent actions due to frustration. Frustration implies the feeling of tension and anger arising from perceived deprivation from anticipated desire, and generates aggression. Frustration gives birth to aggression, when expectation of the people is cut-short. Aggression is the negative and unwarranted response to the situation arising from frustration. Frustration is classified as either absolute or relative. It is absolute, when the people have no alternative or resources to live on in the society, and relative, when the people have resources to live on, but such resources are viewed as inadequate when compared to the resources at the disposal of others in the same society with them. This frustration, irrespective of the perspective generates aggression and graduates to violence in the society.

Niger Delta region is a region blessed with abundant oil and gas resources, and has been the main stay of Nigerian economy. However, though the resources from the region provide the major revenue for the development of Nigerian State, the region appears to be neglected in terms of development activities. The people of the region expect that with the huge revenue from the abundant oil and gas resources, their communities should be 
adequately provided for. On the contrary, the expectations of the people are cut-short, as they are neglected and deprived of the desired development. These neglect and deprivation resulted in frustration of the people, and graduated into anger and subsequent formation of various armed groups (ethnic militia, cult groups and gangs) as social movements and classified as Non-State Security Actors in the region with aggressive and violent actions demanding for control of their resources and development of their rural communities. Some armed groups see the frustration as absolute, while others see it as relative; and from what-ever perspective, their frustration informs their aggressive behaviour and violent activities in their rural communities, with its attendant effects on their communities' development

\section{Findings of the study}

\section{The characteristics of the Non-State Security Actors in Niger Delta}

Command structure: Like the State Security Agents, the NonState Security Actors in Niger Delta region operates with a command structure and is independent in their operations and activities from the state control. The militias, cult groups, and gangs have hierarchical structure, with their leader known as Point 1. The Point 1 is the Commander in Chief, and is assisted by the 2IC in the group. He gives all commands, approves all operations and controls the unit heads, who are in charge of their operating locations and communities. The unit heads supervise operations at their units and report back to the Point 1 for further action. Below the unit heads are the foot soldiers, known as the boys, who carry out the daily operations in their locations and communities on instruction of their boss without complain, as failure to comply with the directives will lead to severe torture and other disciplinary 
actions. The NSSA are internally stratified into upper house known as House of Titan the Great, and lower house known as the Baggers and the Klansman, and there are some differences in their internal mechanisms, but collaborate when necessary for effective operations.

Inter and intra group rivalry and competition: The NSSA has a common problem of inter- and intra-group rivalry and competition among them in their operational base and communities, with each group claiming superiority of operation and power over the order. This superiority is expressed in the rate of arms in their possession and capacity of operations they are able to carry out in their locations. Also, they are associated with internal resistance among themselves, arising from inequality in resource sharing and command structure. This results in constant inter- and intra-armed group rivalry, competition and conflict among them as evidenced in the claim by NDV, NDPVF, Icelanders, Egbesu boys, Isein, Deebam, Deewell, etc to control and possess certain locations and rural communities in the region.

Financial independence: Our finding proves that the NSSA operate on financial independence in the region. They raise their funds through oil bunkering, kidnapping, drugs running, arms for hire, political patronage, community vigilante, security services for oil multinationals, and robbery, and administer the funds for their welfare and further operations. All the funds raised in their operations are accounted to their Point 1 , who pays the unit heads and the boys after every successful operation. However, their financial capacity is determined by the rate of successful operations carried out, as the more successful the operation, the more the funds. They raise their funds and manage same by 
themselves, with each armed group having its internal financial management mechanism.

Spiritual influence for operations: The NSSA rely mainly on spiritual influence for their operations. The armed groups initiate themselves to deities/ancestral homes for power and protection during operations. Egbesu deity in Kaiama community of Ijaw nation, Bayelsa State has been the spiritual home where some armed groups their spiritual powers for operations in the region, while other armed groups obtain source their powers from other shrines. They obtain charms to fortify their body for operations, popularly called "odeshi" or "body tell", meaning body immunity or body sensitivity against attacks from opponents. However, the spiritual powers have limitations, and fail them when they contravene the rules of the deity.

Recruitment and membership: Our interview with some members of the armed groups proved that recruitment into the Non-State Security Actors in Niger Delta region is through ritual initiation and taking oath of secrecy. Membership is open to all individuals who are willing and able irrespective of age, sex, and tribe. Members are recruited voluntarily and/or forcefully into the group, and once recruited; it becomes difficult to leave the group. Some people join the armed groups in the region due to fear and intimidation from members, protection from possible attacks from others, willingness to participate in the operations, and as proof of maturity and test of bravery. However, the old members scout for new members to increase their membership and dominate the community, particularly when they anticipate large operation that will need more members to be successful operation. 
Limited objectives with contradictions: The study observed that the NSSA as armed group has limited operational objectives with contradictions in the region. Its principal mission is to agitate for resource control and development of the region, but practically its objective is to violently attack the state and its institutions, disrupt state activities, cause crisis and instability in their operational locations and communities, and seek for money to maintain themselves and not for the entire people of the region. They are interested in benefiting from the state economic resources, but not taking over and controlling the state powers and structure.

Rural community base operations: The study noted that majority of the Non-State Security Actors such as Deebam, Deewell, Isein, Egbesu Boys, Isongofuro group, Agarafuro group, etc., operate within the rural communities, particularly in communities and locations where oil multinationals and state institutions are located. The actors are quite knowledgeable of the terrain, as they are recruited from the rural communities and have access to operate freely without state security agent's attention on them. The NonState Security Actors choose such locality to enable them easily identify their target audience for violent operations (kidnapping, vandalism, raping, stealing, disruption of state activities, etc), and thereafter, the same community serves as a hideout for them. Some of the actors such as NDVPF, NDV, Port Harcourt Boys, etc, operate both in rural and urban communities, but with limited operations in urban communities due to the resistance of the state security agents.

Use of violence in activities of the Non-State Security Actors: The Non-State Security Actors in Niger Delta region are predominantly armed groups of Niger Delta agitators, who apply 
violence in their agitation process to drive home their demands for resource control and development of the communities in one hand, and their self-satisfaction on the other hand. Their use of violence is perhaps due to the perceived deprivation and frustration, climaxing in aggression and violence. Indeed, the actors are synonymous with violent activities.

Common means of identification among the Actors: Member of the armed group have a common means of identifying themselves and possibly their opponents. The identification includes initiation marks on their body, common language and slangs, and greeting signs among them. The initiation marks are usually made on their back, neck, hand and/or face during initiation into the group. The members use such language and slangs such as "aroow", "area", "barger", etc., for communication, faster identification and cooperation during operations.

\section{Activities of Non-State Security Actors and Rural Community Development in Niger Delta Region}

This section explores the activities of Non-State Security Actors and its implications on rural community development in the region.

Formation and initiation of militias, cult groups, and gangs: the armed groups are formed in the rural communities by aggrieved youths, who agitate firstly for their welfare and later for the development of the region. Membership into the groups is through violent ritual initiation, and in the process some members (both new and old) are wounded, disabled, and killed, leading to group violence, loss of manpower, and human insecurity in such community. On the other perspective, with the continuous initiation of new members, the membership of the group keep 
increasing, while the rebelling members break away to form new armed group, thereby leading to proliferation of armed groups in the rural communities with its attendant implications on the communities. Our study noted that some rural communities such as Tombia, Rumuodogo, Rumuekpe, Rumuji, Agba-Ndele, Nembe, Ozoro, Bomadi, Ekpeye, Ikang, Odoha Emohua, Rumuchie Emohua, Okehi Ecthe, etc., are hotbeds of armed groups' formation and initiation process.

Pipe line vandalism, oil theft and illegal refinery: The militias, cult groups and gangs carry out regular attacks on oil installations in the rural communities, with the intention of breaking the pipe lines to siphon crude oil and either sell the crude oil or take it to their illegal refineries for further processing of condensate for sale, popularly called "asari fuel", "asari diesel" and "asari kerosene". They establish illegal refineries at the water front of the rural communities due to inadequate state security and presence of oil pipe lines in such rural communities. The proceeds from the oil theft and illegal refineries are used for their welfare and to finance their operations. In the process, they destroy the ecosystem of the host and neighbouring communities, through fire disaster, pollution and violent attacks by the State Military Joint Taskforce, killing many people including innocent ones and destroying properties. Prominent among such rural communities are Okirika, Tombia, Bukuma, Degema, Soku, Kula, Abonnema Wharf, Patani, Gbaramatu, etc.

Security capitalism in rural communities: This study sees security capitalism as the private ownership and control of the means of security and its operations for profit making in the Niger Delta region. The ethnic militias and other armed groups have 
become security institutions privately owned and controlled by their leaders (Point 1) for profit purposes in the region. These armed groups provide private security for politicians and wealthy individuals in the communities at a price. In most cases, the armed groups compel celebrants to pay heavily for the security of their ceremony, as failure to pay attracts violent attacks from them. Some of the armed group members are given contract for the surveillance of the oil installations and personnel at a more costly price to avoid them attacking the oil multinationals in the communities. Indeed, security of life and properties in the rural communities has been privatised at an exorbitant price. Security has become "pay as you go", thereby exposing those who cannot pay the high price to security risk in the rural communities. This has resulted in the desertion of some communities with the indigenes running to another community for security.

\section{Providing opportunities for communal crisis through arms} commercialisation: Many scholars, including Wilson (2016) argue that the armed groups provide opportunities for inter and intra communal crisis in the region, through commercialisation of arms and violence. With the sophisticated weapons and ammunitions in their hands and their quest for money, the armed groups instigate crisis in the communities and encourage factions in the crisis to hire their weapons and ammunitions. The armed groups sell their weapons and ammunitions to the crisis communities and offer to operate the arms for attacks and reprisal attacks in such communities based on the prevailing terms of contract with the communities. This escalates to inter and intra communal crisis and accounts for the constant violence in the rural communities that destabilises the peace and development of the region. 
Violent attacks on state institutions and oil multinationals: Our findings noted that the Non-State Security Actors carry out regular violent attacks on the state institutions, oil facilities, and oil company personnel as an expression of their grievances arising from their deprivation and frustration, and subsequent agitations for the development of their communities. With the grievance in them, the political opponents, wealthy individuals and deprived oil company contractors in the communities hire the Non-State Security Actors to carry out violent attacks on state institutions and oil multinationals. In return, the violent attacks destroy the state development institutions and projects in the communities. The attacks on oil multinationals force the later to close their operations in such communities, terminating the appointments of the communities' people working in the company, leaving the communities with numerous redundant and unemployed people, and withdrawal of funds for community development projects in such communities. This was experienced in communities as Rumuekpe, Ibaa, Erema, Tombia, Yeke, Obagi, Obirikom, Akabuka, etc., where such attacks led to the closure of government schools, health centres, markets and withdrawal of oil multinational operations for a period of time, resulting in development set-back for the communities.

\section{Arms resistance and conflict with the State Security Agents: It} is established that most of the armed groups carry out their violent activities in the rural communities, and in attempt for the state security agents to resist and stop them, both the armed groups and state security agents engage in attacks and reprisal attacks leading of destruction of such community and death of many people (including the armed group members and innocent ones). This situation attracts state policy of imposing curfew in such 
community. The gross effect is that lives and properties are lost, movement restricted, and development affected, and in such community.

Community vigilante: The study observed that the armed groups provide community vigilante services in their host communities and are paid for the services. The aim of the community vigilante is to provide security against possible attacks in the community, but the same armed groups turn to create more security challenge for the communities. Firstly, their presence as community vigilante attracts other armed groups, usually the opponents to attack them and the host community leading to destruction of lives and properties in such community. Secondly, the armed groups indulge in criminal activities such as picking pocket, forcefully taxing and collecting money from people, looting and stealing properties, and raping young girls at the farm and water side. These activities constitute mega security threat and affect the community development.

\section{Strategies to curb the activities of Non-State Security Actors in the communities of Niger Delta region}

The study proffers the following strategies to curb the activities of the Non-State Security Actors in the region.

$>$ We acknowledge the efforts of the state through the use of Joint Military Task Force (JMTF) to fight the NSSA in the region, but noted the Joint Military Task Force activities are inadequate. The State should therefore moblise the Joint Military Task Force (JMTF) with adequate capacity of personnel and equipment to intensify operations at the rural communities to resist the activities of the armed groups and 
mop-up the weapons and ammunitions in their possession in the region.

$>$ Effective implementation of the State Amnesty Programmes in the region in the area of re-orientation of the armed group members, with view to changing their agitation philosophy to sustainable development for the region.

$>$ Adequate re-investment of oil and gas revenue derived from the region back to the region for both human and rural community development.

$>$ Intensive capacity building for the youths through manpower training and development and thereafter providing employment for them. This will discourage the idle youths from joining the armed groups for survival.

$>$ Establishment of effective government - community relations units to enable the state monitor the communities' activities.

$>$ Engagement of the armed group members in community security with government regulation of their activities.

$>$ State regulation of oil multinational activities in its host communities.

$>$ Oil multinationals to keep away from youth and community leadership politics in their host community.

$>$ Politicians, wealthy individuals and oil multinationals should stop patronising the armed groups for private security, with the view discouraging the armed groups in the region.

$>$ Individuals and communities should stop hiring the weapons and ammunitions of the armed groups as to stop their arms hire business and starving them of funds for survival. 
In conclusion, it is the position of this study that marginalisation, deprivation and bad governance gave rise to emergence of NonState Security Actors in Niger Delta region. The Non-State Security Actors are armed youths in the region who carry out several violent activities to satisfy themselves at the detriment of their host communities. The contradiction of the existence of the Non-State Security Actors in the region is that the people of the region suffer great harm, while the Non-State Security Actors claim to be fighting for the people's welfare. The Non-State Security Actors have peculiar characteristics associated with their activities, and their activities have significant negative effects on the rural community development in the region. However, it is our view that when the study recommendations are applied, it will go a long way to reduce the armed groups' violent activities and enhance rural community development in the region.

\section{Goddey Wilson}

Department of Political Science

Ignatius Ajuru University of Education, Port Harcourt goddey.wilson@gmail.com 


\section{References}

Biggs, S. (1999) Community capacity building in Queensland : The Queensland Government service delivery project. Unpublished paper. Office of rural communities. Brisbang Queensland.

Carson, B. (2017) Community development. www.portal.hud.gov/hudportal. Retrieved on 04/09/2017.

Crossman, A. (2014) Frustration-Aggression Theory. www.thoughtco.com/frustration- aggression-theory3026333.

DCAF \& Geneva Call (2015) Armed Non-State Actors: Current trends \& futures. DCAF Horizon 2015 working paper.

Dollard, J., Dood, L.W., Miller, N.E., Mowrer, O.H., \& Sears, R.R. (1939) Frustration- Aggression. New Haven : Yale University Press.

Ekanamah, A. (2010) Managing post-amnesty era in the Niger Delta. Business World. January, $15^{\text {th }}$.

Englehart, N. A. (2016) Non-state armed groups as a threat to global security: what threat, whose security? Journal of Global Security Studies 1(2), 171-183.

European Commission (2012) The Cotonou Agreement. May $10^{\text {th }}$.www.ec.europa.eu/europeaid/where/acp/overview/cont onou- agreement/index-enhtm. Retrieved on 10/09/2017

Flora, C. D. \& Flora, J.L. (1993) Entrepreneurial social infrastructure: A necessary ingredient. Annals of the American Academy of Political and Social Sciences 539. 48-58.

Kemedi, D. V. (2006) Fuelling the violence : Non-State armed actors ( militias, cults, and gangs) in the Niger Delta. Niger Delta : Economies of violence. Working 
paper No: 10. Institute of International Studies, University of California, Berkeley, USA.

Miller, N.E., Sears, R.R., Mowrer, O.H., Dood, L.W., \& Dollard, J. (1941) The frustration- aggression hypothesis. Institute of Human Relations, Yale University.

Rosenthal, J.A. (2008) For profit terrorism : The rise of armed entrepreneurs. Studies in conflict and terrorism 31(6), 481-498.

Whitley, B., \& Kite, M. (2010) The psychology of prejudice and discrimination. Belmont, C.A : Cengage Learning.

Wilson, G. (2012) Militancy in the Niger Delta region and its impact on Nigerian State. International Journal of Educational Development. 2(1). 55-67.

Wilson, G. (2014) The Nigerian State and oil theft in the Niger Delta region of Nigeria. Journal of Sustainable Development in Africa. 16(1), 69-81.

Wilson, G. (2016) The impact of militancy and cult groups' activities on Rundele community development in Niger Delta region of Nigeria. International Journal of Arts and Humanities 5(4), 49-62. 